\title{
Effect of cream pasteurization, microfiltration and enzymatic proteolysis on in vitro cholesterol-lowering activity of buttermilk solids
}

\author{
Valérie Conway, Sylvie F. Gauthier, Yves Pouliot* \\ STELA Dairy Research Center and Institute of Nutraceuticals and Functional Foods (INAF), \\ Université Laval, Quebec City, QC, G1V 0A6, Canada
}

Received 5 June 2009 - Revised 12 February 2010 - Accepted 22 March 2010

Published online 28 May 2010

\begin{abstract}
The lipids and proteins of buttermilk solids have been associated with several potential health benefits. In this work, the effect of cream pasteurization, microfiltration (MF) and enzymatic proteolysis on the chemical composition and cholesterol-lowering activity of buttermilk solids was studied. Buttermilk was made from pasteurized or unpasteurized cream and fractionated using a $0.5-\mu \mathrm{m}$ MF membrane or treated with pepsin or pepsin followed by trypsin. The cholesterollowering activity of the products obtained was measured as micellar solubility of cholesterol in vitro. This value was reduced significantly by $57.1 \%$ of the control in the presence of raw-cream buttermilk, while buttermilk from pasteurized cream had a much lower impact (reduction of $17.0 \%$ ). These results suggest a strong inhibitory effect of components in raw-cream buttermilk on in vitro micellar solubility of cholesterol. MF retentate and permeate of buttermilks made from either cream had smaller effects on micellar solubility. Enzymatic hydrolysis of buttermilk made from pasteurized cream seemed to restore the lost cholesterol-lowering activity.
\end{abstract}

buttermilk / milk fat globule membrane / pasteurization / microfiltration / cholesterol-lowering activity / enzymatic hydrolysis

\begin{abstract}
摘要 - 巴氏杀菌奶油、微滤和蛋白水解酶对固态酪乳体外降胆固醇活性的影响。固 态 酪 乳中的脂肪和蛋白质与人体潜在的健康问题紧密相关。本文研究了巴氏杀菌、微滤 (MF) 和蛋白酶水解奶油对固态酪乳化学成分和降胆固醇活性的影响。采用巴氏杀菌奶油 制成酪乳, 或未经巴氏杀菌而使用 0.5 微米微滤膜分级得到的奶油以及经胃蛋白酶处理或 以胰蛋白酶酶解再用胃蛋白酶处理的奶油。对产品中体外降胆固醇活性则通过测定胆固醇 胶束的溶解度来表示。从生鲜奶油分离出来酪乳的降胆固醇活性显著降低 $57.1 \%$, 而从巴 氏杀菌奶油中得到的酪乳则影响很低 (减少 $17.0 \%$ )。结果显示以生鲜奶油分离得到的酪 乳成分对胆固醇胶束溶解度有较强的抑制作用。酪乳的 MF 滞留物和透过液对胶束溶解 度影响较小。酶法水解巴氏杀菌奶油得到的酪乳恢复了降胆固醇活性。
\end{abstract}

\section{酪乳 / 乳脂肪球膜 / 巴氏杀菌 / 微滤 / 降胆固醇活性 / 酶水解}

Résumé - Effet de la pasteurisation de la crème, du fractionnement par microfiltration et de la protéolyse enzymatique sur l'activité hypocholestérolémiante in vitro des solides du babeurre. Les lipides et protéines du babeurre sont associés à différentes activités biologiques bénéfiques pour la santé. Le but de cette étude était de mesurer l'effet de la pasteurisation de la

*Corresponding author (通讯作者): Yves.Pouliot@inaf.ulaval.ca 
crème, de la microfiltration (MF) et de la protéolyse enzymatique sur la composition chimique et l'activité anti-cholestérol des solides du babeurre. Des babeurres issus de crèmes crues ou pasteurisées ont été fractionnés à l'aide d'une membrane de $0,5 \mu \mathrm{m}$ ou hydrolysés à l'aide de pepsine ou de pepsine suivie de trypsine. L'activité hypocholestérolémiante des produits ainsi obtenus a été mesurée en termes de solubilité micellaire du cholestérol in vitro. Une réduction de 57,1\% par rapport au témoin a été obtenue en présence du babeurre issu de crèmes crues, tandis que l'impact du babeurre issu de crèmes pasteurisées était plus faible (réduction de 17,0\%). Ces résultats suggèrent la présence, dans le babeurre issu de crèmes crues, de composants inhibant fortement la solubilité micellaire du cholestérol in vitro. Les rétentats et perméats des babeurres issus des crèmes crues ou pasteurisées ont eu des effets moins importants sur la solubilité micellaire du cholestérol. L'hydrolyse enzymatique du babeurre issu de crèmes pasteurisées a permis de rétablir, au moins en partie, l'activité hypocholestérolémiante perdue.

babeurre / membrane de globule de gras / pasteurisation / microfiltration / activité hypocholestérolémiante / hydrolyse enzymatique

\section{INTRODUCTION}

Buttermilk is the liquid by-product resulting from the churning of cream in butter manufacture. Fragments of the milk fat globule membrane (MFGM) end up in the buttermilk along with most of the water-soluble cream components such as lactose, minerals and milk proteins. MFGM fragments are believed to be partly responsible for the distinctive characteristics of buttermilk as a functional ingredient [27]. Although its overall composition is similar to skim milk, buttermilk is known for its relatively high concentration of MFGM polar lipids. The phospholipid content of buttermilk can reach up to seven times that of whole milk [25]. Mainly composed of phosphatidylethanolamine (PE), phosphatidylcholine (PC), sphingomyelin (SM), phosphatidylinositol (PI), phosphatidylserine (PS), glucosylceramide (GluCer) and lactosylceramide (LacCer), MFGM phospholipids have been associated recently with numerous health benefits such as protective effects against cancer, stress, Alzheimer's disease and gastrointestinal pathogens as well as hypercholesterolaemia as reviewed in $[4,24,26]$. For example, SM, which represents approximately $25 \%$ of the MFGM phospholipids, has been shown to reduce intestinal absorption of cholesterol in rats
$[6,12,21]$. One of the possible explanations for this effect is the slowness of SM hydrolysis in the gastrointestinal tract. This phenomenon may slow down the hydrolysis of other lipids and hence micelle formation, thus reducing cholesterol absorption [20]. Other hypotheses for the hypocholesterolaemic effects of SM are based on its strong chemical affinity for cholesterol and its incomplete digestion, giving this phospholipid the capacity to bind cholesterol throughout the small intestine [6]. Nagaoka et al. [19] have suggested that decreasing the micellar solubility of cholesterol can suppress its absorption and therefore plays an important role in hypocholesterolaemia.

In spite of growing interest and knowledge regarding health benefits of MFGM components, most of the published work has focused on purified MFGM molecules and has not considered the bioactivity of MFGM fragments as a whole, for example, in complex mixtures of membrane proteins and polar lipids in a dairy matrix such as buttermilk. Moreover, the impact of different buttermilk processing technologies and enzymatic hydrolysis has not yet been studied. It is known that heat processing of cream modifies the composition and structure of MFGM to a considerable extent $[8,24]$. Heat treatment denatures whey and MFGM proteins, resulting in the 
formation of various complexes with caseins $[3,5,8,29]$. These heat-induced interactions are likely to modify the bioactivity and functional properties of MFGM.

The objective of this work was to compare the composition and in vitro cholesterol-lowering activity of buttermilk solids obtained from raw and pasteurized cream and hence the potential impact of processing on their in vivo reduction of cholesterol micellar solubility. Buttermilk fractions obtained by microfiltration (MF) or by sequential hydrolysis with pepsin and trypsin were also examined.

\section{MATERIALS AND METHODS}

\subsection{Processing conditions}

Fresh raw cream was purchased from a local dairy (Natrel, QC, Canada) in 100-kg batches. Each batch was divided into two portions upon reception, one of which was pasteurized (Pasteurizer Actini, Évian-LesBains, France) without delay at $85{ }^{\circ} \mathrm{C}$ for $20 \mathrm{~s}$ and rapidly cooled to $10^{\circ} \mathrm{C}$, while the other was placed at $10^{\circ} \mathrm{C}$. Both portions were kept overnight at $10^{\circ} \mathrm{C}$ and processed the following day in a rotary churn at $13{ }^{\circ} \mathrm{C}$ and $26 \mathrm{rpm}$ until buttermilk was expelled. The buttermilk was passed through a stainless steel filter to remove butter particles and then skimmed at $37^{\circ} \mathrm{C}$ using a milk separator (Alpha-Laval, Lund, Sweden). A sample was removed and cooled rapidly and the rest was microfiltered with co-current recirculation of permeate using a Bactocatch ${ }^{\mathrm{TM}}$ module (Tetra Pak, Lund, Sweden) containing $0.5-\mu \mathrm{m}$ ceramic membrane (Membralox P35-37, Pall Corporation, Mississauga, ON, Canada). MF was done until the retentate volume was reduced threefold. The retentate was restored with tap water to its initial volume and re-filtered until reduced fourfold in volume (diafiltration, in effect). Pressure and temperature were maintained constant at $50 \mathrm{kPa}$ and $45-50{ }^{\circ} \mathrm{C}$. The final MF retentate and permeate were cooled rapidly at $4{ }^{\circ} \mathrm{C}$. All samples (buttermilk, MF permeate and retentate) were freeze dried and the recovered powders were stored frozen $\left(-35^{\circ} \mathrm{C}\right)$. The above processing procedure was done on four batches of cream $(n=4)$.

The MF membrane was cleaned after each batch by rinsing with deionized water followed by circulation of alkaline cleaner (1.5\% (v/v) Ultrasil 25, EcoLab, St. Paul, MN, USA) containing $200 \mathrm{ppm}$ of chlorine for $45 \mathrm{~min}$ at $75^{\circ} \mathrm{C}$. The system was then rinsed with warm deionized water $\left(50-60{ }^{\circ} \mathrm{C}\right)$ until the normal water $\mathrm{pH}$ was reached and acid detergent $(0.3 \%(\mathrm{v} / \mathrm{v})$ Ultrasil 76, EcoLab) was then circulated for $30 \mathrm{~min}$ at $50{ }^{\circ} \mathrm{C}$. The system was then rinsed with deionized water until the normal water $\mathrm{pH}$ was reached. The cleaning procedure was repeated until the initial water flux was restored.

\subsection{Chemical analysis}

All chemical analyses were performed in triplicate. Moisture and ash contents were determined gravimetrically by drying at $100{ }^{\circ} \mathrm{C}$ for $4 \mathrm{~h}$ in a drying oven followed by incineration in a muffle furnace at $550{ }^{\circ} \mathrm{C}$ for $24 \mathrm{~h}$. Protein content was determined by the Dumas combustion method [9] using an FP-528 Leco apparatus (Leco Corp., St. Joseph, MI, USA). The calibration standard curve was prepared using ammonium sulphate $(99.99 \% \mathrm{w} / \mathrm{w}$, Sigma-Aldrich, Oakville, ON, Canada) and nitrogen content was converted to protein using the milk conversion factor (6.38). Differences in buttermilk MFGM protein distribution among MF retentate and permeate (pasteurized and unpasteurized) were assessed by sodium dodecyl sulphate polyacrylamide gel electrophoresis (SDS-PAGE) using a $12.5 \%$ polyacrylamide gel under reducing conditions as described elsewhere [13]. Relative protein distribution in the samples was obtained 
by densitometry using Quantity One software from BioRad. Individual proteins were identified using a pre-stained SDS-PAGE MW broad range standard (Bio-Rad laboratories, Hercules, CA, USA). The protein bands were assigned according to Mather [14]. Lipids were extracted using a gravimetric extraction method [10], then weighed and diluted in 2:1 chloroform:methanol mixture to a final lipid concentration of $10 \mathrm{mg} \cdot \mathrm{mL}^{-1}$. All lipid samples were stored at $-20{ }^{\circ} \mathrm{C}$ until further analysis. Differences in buttermilk phospholipid distribution among MF retentate and permeate (pasteurized and unpasteurized) were assessed using high-performance liquid chromatography with evaporative light scattering detector (HPLC-ELSD) as described by Morin et al. [17]. The various phospholipid peaks were assigned using phospholipid standards, according to the work of Rombaut and Dewettinck [23]. For comparative purpose, the relative proportion of each phospholipid was estimated by determining its individual peak area compared to the total surface area of the chromatogram.

\subsection{Measurement of the in vitro micellar solubility of cholesterol}

The in vitro micellar solubility of cholesterol in the presence of whole buttermilk solids, MF permeate, MF retentate, peptic hydrolysate and peptic/tryptic hydrolysate (see below) was measured in triplicate according to the method of Ikeda et al. [11] with some modifications. Micellar solution $(10 \mathrm{~mL})$ was prepared in $15 \mathrm{mmol} \cdot \mathrm{L}^{-1}$ sodium phosphate buffer $(\mathrm{pH} 7.4)$ containing $6.6 \mathrm{mmol} \cdot \mathrm{L}^{-1}$ sodium taurocholate, $\quad 0.5 \mathrm{mmol} \cdot \mathrm{L}^{-1}$ cholesterol, $1 \mathrm{mmol} \cdot \mathrm{L}^{-1}$ oleic acid, $0.65 \mathrm{mmol} \cdot \mathrm{L}^{-1} \mathrm{PC}$, $132 \mathrm{mmol} \cdot \mathrm{L}^{-1} \mathrm{NaCl}$ and $200 \mathrm{mg}$ of freeze-dried sample. The mixture was sonicated at $37{ }^{\circ} \mathrm{C}$, incubated at the same temperature for $24 \mathrm{~h}$ and then centrifuged at $10000 \times g$ (Beckman Coulter Optima
MAX ultracentrifuge, TLA 100.3 rotor, Fullerton, CA, USA) at $37{ }^{\circ} \mathrm{C}$. Cholesterol was extracted from the supernatant using hexane after $1 \mathrm{~h}$ of saponification with $0.5 \mathrm{~mol} \cdot \mathrm{L}^{-1} \mathrm{KOH}$ at $60^{\circ} \mathrm{C}$ and determined using a colorimetric method with $o$-phthaldialdehyde in a mixture of acetic and sulphuric acids (2:1) as proposed by Zlatkis and Zak [30]. Absorbance was measured at $550 \mathrm{~nm}$ against a blank consisting of $o$-phthaldialdehyde in the same acidic mixture. Results were expressed relative to a cholesterol reference made without the $200 \mathrm{mg}$ of sample.

\subsection{In vitro enzymatic hydrolysis of buttermilk}

The four replicate batches of buttermilk solids obtained from raw or pasteurized cream were pooled for the purpose of this experiment (to make the samples more representative). The conditions selected for peptic hydrolysis were based on the physiological parameters described in the user's manual for the TNO dynamic gastrointestinal simulator (TIM) developed by Minekus et al. [16], with some modifications. The following procedure was done in triplicate. Buttermilk solution (1000 g) was prepared at $5 \%$ protein $(\mathrm{w} / \mathrm{w})$ in gastric salts mixture $\left(52 \mathrm{mmol} \cdot \mathrm{L}^{-1} \mathrm{NaCl}, 15 \mathrm{mmol} \cdot \mathrm{L}^{-1} \mathrm{KCl}\right.$, $1 \mathrm{mmol} \cdot \mathrm{L}^{-1} \quad \mathrm{CaCl}_{2}$ and $7 \mathrm{mmol} \cdot \mathrm{L}^{-1}$ $\mathrm{NaHCO}_{3}$ ) and stirred overnight at $4{ }^{\circ} \mathrm{C}$. Peptic hydrolysis was then done at $37^{\circ} \mathrm{C}$ and $\mathrm{pH} 2.0$ (adjusted with $1 \mathrm{~mol} \cdot \mathrm{L}^{-1} \mathrm{HCl}$ ) for $2 \mathrm{~h}$ with stirring. Porcine pepsin (EC 3.4.23.1, 2500-3500 U.mg ${ }^{-1}$ protein, Sigma-Aldrich) was used at an enzyme to substrate mass ratio of 1:100. Samples were removed before and after hydrolysis. The $\mathrm{pH}$ was then adjusted to 8.0 with $1 \mathrm{~mol} \cdot \mathrm{L}^{-1}$ $\mathrm{NaOH}$ and bovine trypsin (EC 3.4.21.4, Type I, 10000 BAEE $\cdot \mathrm{U} \cdot \mathrm{mg}^{-1}$ protein, Sigma-Aldrich) was added at an enzyme to substrate mass ratio of $1: 250$. After $3 \mathrm{~h}$ 
of tryptic hydrolysis, the enzymes were removed using an ultrafiltration (UF) system equipped with a $30 \mathrm{~kg} \cdot \mathrm{mol}^{-1}$ molecular weight cut-off (MWCO) polyethersulphone membrane (Prep/scale TM_TFF $0.0929 \mathrm{~m}^{2}$ cartridge, Millipore Corp., Bedford, MA, USA). Pressure and temperature were maintained constant at $14 \mathrm{MPa}$ and $37{ }^{\circ} \mathrm{C}$ until the retentate was concentrated fivefold. Tap water $\left(37^{\circ} \mathrm{C}\right)$ was then added to restore the initial volume. The filtration was then continued until the retentate was re-concentrated fourfold (diafiltration). The pooled UF permeate thus represents the completed (peptic and tryptic) hydrolysis. All samples were freeze dried and kept at $-35^{\circ} \mathrm{C}$ until further analysis.

\subsection{Statistical analysis}

Treatment effects were subjected to twoway analysis of variance using a general linear model procedure of SAS 9.1.3 Service Pack 2 software (SAS Institute Inc., Cary, NC, USA). All values are displayed as mean \pm standard error of the mean (SEM) and considered statistically different if $P<0.05$.

\section{RESULTS}

\subsection{Effect of cream pasteurization and MF fractionation on buttermilk composition}

The ash, protein and lipid contents of all samples, expressed as \% of dry matter, are presented in Figure 1. The slightly higher ash content of MF permeate is likely due to the diafiltration step. As expected, protein and lipid contents are concentrated in MF retentate. Pasteurizing the cream had a greater impact on lipid content than on the other components: $7.4 \%$ in buttermilk solids and $18.2 \%$ in MF retentate, compared to
$6.2 \%$ and $13.5 \%$, respectively, in the corresponding products from raw cream $(P=0.0131)$. There were no significant differences between the four replicate batches of buttermilks for ash, protein or lipid contents (Tab. I). MF fractionation also induced a highly significant difference $(P<0.0001)$ in protein contents and significant interactions were observed between buttermilks and MF fractions as well as between MF permeates and MF retentates. Significant interactions were also observed between heat treatment and MF fractions for ash and lipid contents but not for protein content.

The phospholipid (PL) relative proportions (glycerophospholipids and sphingolipids) of samples are shown in Table II. At $29-40 \%$ and $32-39 \%, \mathrm{PE}$ and PC were the most abundant phospholipids, followed by SM (12-14\%), PI (6-8\%), LacCer $(1-9 \%)$ PS $(1-4 \%)$ and GluCer $(0.1-0.7 \%)$. Overall, PE, PC and SM accounted for more than $70 \%$ of the buttermilk phospholipids. As shown in Table II, the batch effect and the heat treatment effect were both significant for LacCer, PI and $\mathrm{SM}$, making it difficult to reach a clear conclusion about the effect of heat treatment on these specific phospholipids. As proposed by Morin et al. [18], processing might have induced an aggregation of some phospholipids resulting in decreased solubility in extraction solvent. However, MF fractionation clearly affected the PE and PC contents significantly but in the opposite manner, PE content increasing in MF retentates, while PC increased in MF permeates, in both cases regardless of cream processing. No significant interaction between cream heat treatment and MF fractionation of the buttermilks was observed.

Figure 2 presents the SDS-PAGE patterns of the buttermilks, MF permeates and MF retentates. Five different bands were associated with MFGM proteins, 

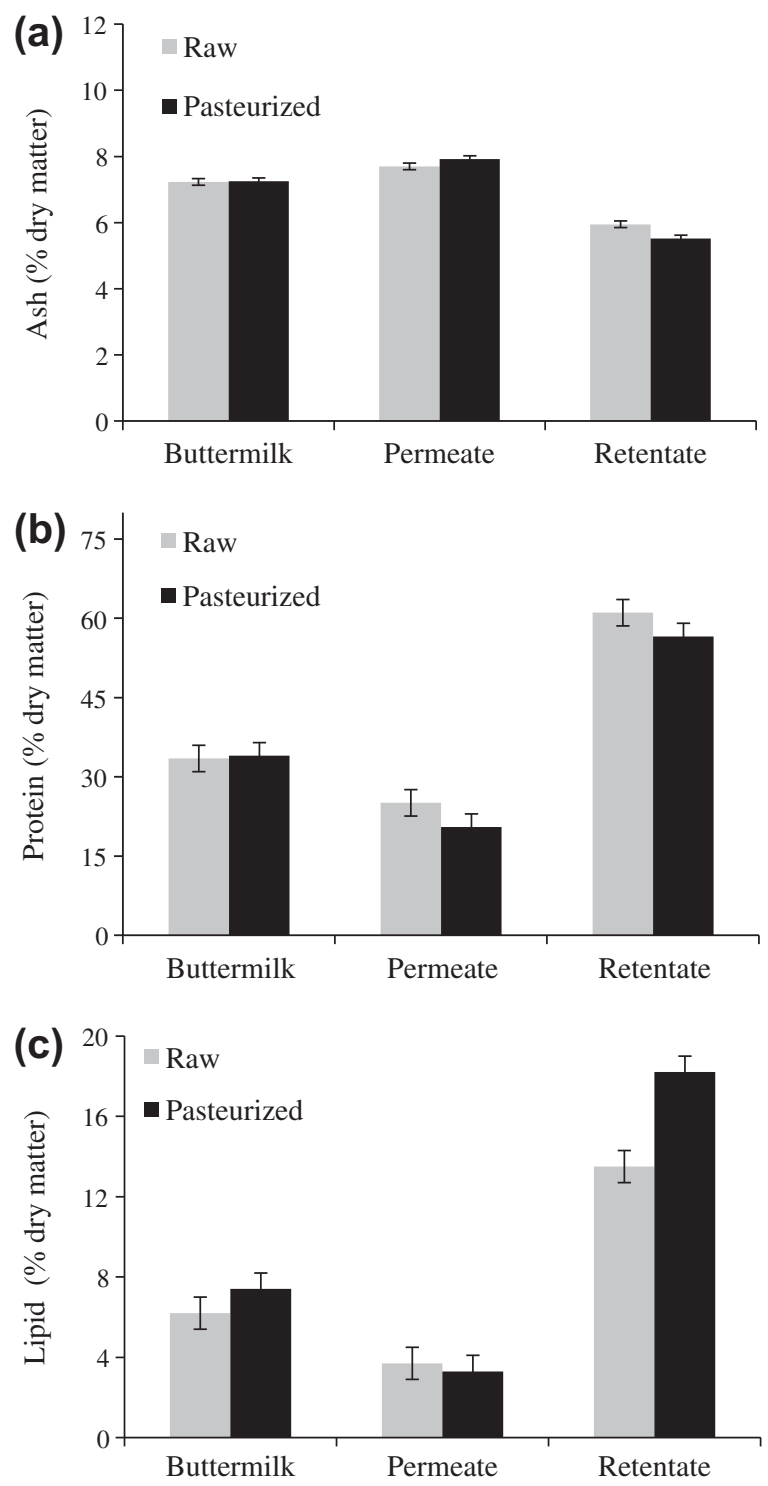

Figure 1. Effect of cream pasteurization on the ash (a), protein (b) and lipid (c) contents (\% dry matter) of buttermilk and its MF fractions (mean \pm standard error of the mean, $n=4$ ).

three with milk caseins $(\alpha-, \beta-$ and $\kappa-\mathrm{CN})$ and two with the major whey proteins, $\beta$-lactoglobulin ( $\beta$-LG) and $\alpha$-lactalbumin $(\alpha$-LA). MFGM proteins were present in all six samples tested. Densitometry measurements (data not shown) revealed that the most intense MFGM bands were observed for the two MF retentates 
Table I. Statistical significance of heat treatment (of the cream) and of MF on the ash, protein and lipid contents of buttermilk.

\begin{tabular}{lccc}
\hline Comparison & \multicolumn{3}{c}{ Significance $(P$ value $)$} \\
\cline { 2 - 4 } & Ash & Protein & Lipid \\
\hline Replicate batches & N.S. & N.S. & N.S. \\
Heat treatment & N.S. & N.S. & 0.0131 \\
Fractionation $(M F)$ & $<0.0001$ & $<0.0001$ & $<0.0001$ \\
$-($ Buttermilk $) \times($ Permeate \& Retentate $)$ & $<0.0001$ & 0.0128 & 0.0028 \\
$-($ Permeate $) \times($ Retentate $)$ & $<0.0001$ & $<0.0001$ & $<0.0001$ \\
$($ Heat treatment $) \times($ Fractionation $)$ & 0.0023 & N.S. & 0.0183 \\
$-($ Buttermilk $) \times($ Heat treatment $) \times($ Permeate \& Retentate $)$ & N.S. & N.S. & N.S. \\
$-($ Heat treatment $) \times($ Permeate $) \times($ Retentate $)$ & 0.0007 & N.S. & 0.0060 \\
\hline
\end{tabular}

${ }^{\mathrm{a}}$ N.S. $=$ non-significant $(P>0.05)$.

Table II. Relative proportions (\%) ${ }^{\mathrm{a}}$ of phospholipids ${ }^{\mathrm{b}}$ measured in buttermilk solids obtained from raw or pasteurized cream and in the fractions obtained by microfiltration (MF permeate and MF retentate).

\begin{tabular}{|c|c|c|c|c|c|c|c|}
\hline Fraction & GluCer & LacCer & $\mathrm{PE}$ & PI & PS & $\mathrm{PC}$ & SM \\
\hline \multicolumn{8}{|l|}{ From raw cream } \\
\hline Buttermilk & 0.7 & 4.3 & 36.6 & 6.9 & 2.5 & 33.4 & 12.1 \\
\hline MF permeate & 0.3 & 9.0 & 29.0 & 6.7 & 1.4 & 37.6 & 11.5 \\
\hline MF retentate & 0.4 & 6.7 & 36.7 & 6.1 & 2.7 & 32.0 & 11.7 \\
\hline \multicolumn{8}{|l|}{ From pasteurized cream } \\
\hline Buttermilk & 0.6 & 1.6 & 39.9 & 7.1 & 3.6 & 30.7 & 13.0 \\
\hline MF permeate & 0.1 & 2.6 & 30.4 & 7.5 & 2.4 & 38.8 & 13.5 \\
\hline MF retentate & 0.2 & 1.2 & 33.6 & 7.1 & 2.5 & 32.5 & 13.6 \\
\hline $\operatorname{SEM}(n=4)$ & 0.2 & 0.9 & 1.9 & 0.4 & 0.4 & 1.3 & 0.5 \\
\hline Comparison & \multicolumn{7}{|c|}{ Significance ( $P$ value) } \\
\hline Replicate batches & N.S. ${ }^{\mathrm{c}}$ & 0.0446 & N.S. & 0.0008 & N.S. & N.S. & 0.0103 \\
\hline Heat treatment & N.S. & $<0.0001$ & N.S. & 0.0248 & N.S. & N.S. & 0.0015 \\
\hline Fractionation (MF) & N.S. & N.S. & 0.0045 & N.S. & N.S. & 0.0008 & N.S. \\
\hline - (Buttermilk) $\times($ Permeate \& Retentate $)$ & N.S. & N.S. & 0.0097 & N.S. & N.S. & 0.0324 & N.S. \\
\hline$-($ Permeate $) \times($ Retentate $)$ & N.S. & N.S. & 0.0113 & N.S. & N.S. & 0.0005 & N.S. \\
\hline$($ Heat treatment $) \times($ MF fractions $)$ & N.S. & N.S. & N.S. & N.S. & N.S. & N.S. & N.S. \\
\hline
\end{tabular}

${ }^{\text {a }}$ Individual peak area relative to the total HPLC-ELSD chromatogram surface area.

${ }^{\mathrm{b}}$ GluCer = glucosylceramide; LacCer = lactosylceramide; PE = phosphatidylethanolamine; PI = phosphatidylinositol; $\mathrm{PS}=$ phosphatidylserine; $\mathrm{PC}=$ phosphatidylcholine; $\mathrm{SM}=$ sphingomyelin .

${ }^{\mathrm{c}}$ N.S. $=$ non-significant $(P>0.05)$.

(lanes 5 and 6). The whey protein bands $(\beta$-LG and $\alpha$-LA) were more intense in the MF retentate from pasteurized cream (lane 6) compared to raw cream (lane 5). 


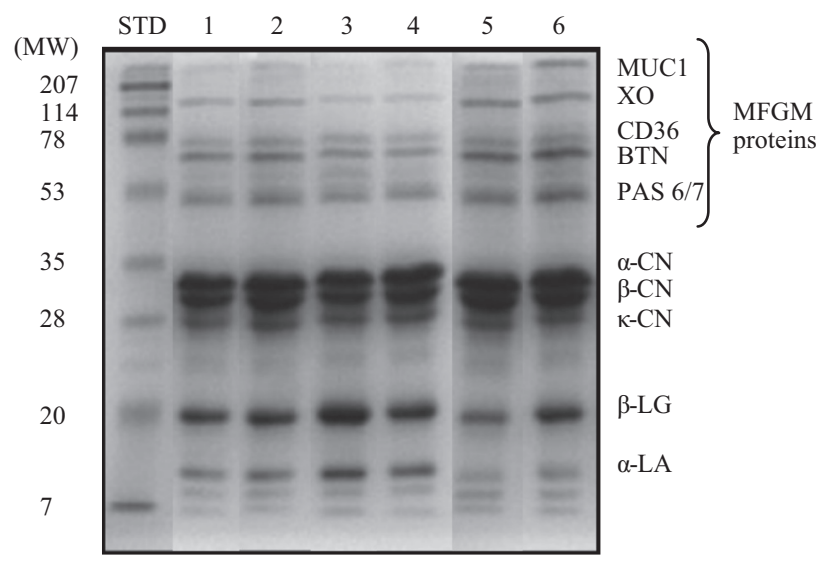

Figure 2. SDS-PAGE (under reducing conditions) profiles of proteins in buttermilk made from raw or pasteurized cream. STD = molecular weight $(\mathrm{MW})$ standard; 1 = buttermilk from raw cream; $2=$ buttermilk from pasteurized cream; $3=$ MF permeate (raw); $4=$ MF permeate (pasteurized); $5=\mathrm{MF}$ retentate (raw); $6=\mathrm{MF}$ retentate (pasteurized). Protein bands are: $\mathrm{MUC1}=$ mucin 1 ; $\mathrm{XO}=$ xanthine oxidase; $\mathrm{CD} 36=$ cluster of differentiation; $\mathrm{BTN}=$ butyrophilin; PAS $6 / 7=$ periodic acid Schiff $6 / 7 ; \alpha-\mathrm{CN}=\alpha$-casein; $\beta$-CN $=\beta$-casein; $\kappa-\mathrm{CN}=\kappa$-casein; $\beta$-LG $=\beta$-lactoglobulin; $\alpha$-LA $=\alpha$-lactalbumin.

\subsection{Effect of cream pasteurization and MF fractionation on the in vitro cholesterol micellar solubility}

The effects of cream pasteurization and MF fractionation on the cholesterol micellar solubility in the presence of buttermilk solids are presented in Table III. The greatest reduction of in vitro cholesterol solubility $(57.1 \%)$ was obtained in the presence of buttermilk solids obtained from raw cream. Pasteurization of the cream led to a higher in vitro cholesterol micellar solubility $(83.3 \%)$ in the presence of buttermilk solids compared to buttermilk solids obtained from raw cream $(42.9 \%)$. MF fractionation of buttermilk from raw or pasteurized cream had the same effects. As shown in Table III, the effect of heat treatment is highly significant $(P=0.001)$ and that of MF fractionation is also significant $(P=0.0121)$, while the significance of the interaction between whole buttermilks and MF fractions was in between $(P=0.0038)$. No significant MF permeate $\times$ MF retentate or heat treatment $\times \mathrm{MF}$ fraction interaction was observed.

\subsection{Effect of proteolysis on the cholesterol micellar solubility in the presence of buttermilk solids obtained from raw and pasteurized cream}

The effects of proteolysis by pepsin and trypsin on the ability of buttermilk solids to reduce the cholesterol micellar solubility are shown in Table IV. First, a large increase in micellar solubility in the presence of nonhydrolysed buttermilk from both raw and pasteurized cream was noted in comparison with the values in Table III. This is likely due to the use of the gastric salts mixture, which appears to have increased the solubility of cholesterol. Nevertheless, the effects of the treatments are still apparent. Pasteurization still had a negative impact on the 
Table III. Cholesterol micellar solubility determined in vitro in the presence of buttermilk solids and MF fractions made from raw or pasteurized cream.

\begin{tabular}{lc}
\hline Fraction & Cholesterol micellar solubility $^{\mathrm{a}}(\%)$ \\
\hline From raw cream & \\
Buttermilk & 42.9 \\
MF permeate & 73.2 \\
MF retentate & 67.2 \\
From pasteurized cream & \\
Buttermilk & 83.0 \\
MF permeate & 93.7 \\
MF retentate & 93.5 \\
SEM $(n=4)$ & 3.3 \\
Comparison & Significance $(P$ value $)$ \\
\hline Replicate batches & N.S. ${ }^{\mathrm{b}}$ \\
Heat treatment & 0.0010 \\
Fractionation $(M F)$ & 0.0121 \\
$\quad-($ Buttermilk $) \times($ Permeate \& Retentate $)$ & 0.0038 \\
$-($ Permeate $) \times($ Retentate $)$ & N.S. \\
(Heat treatment $) \times($ MF fractions $)$ & N.S. \\
\hline
\end{tabular}

${ }^{a}$ Relative to micellar cholesterol solution without buttermilk product.

${ }^{\mathrm{b}}$ N.S. $=$ non-significant $(P>0.05)$.

cholesterol micellar solubility in vitro in nonhydrolysed buttermilk. Though no significantly (Tab. IV), cholesterol solubility seems to increase slightly in the presence of the product hydrolysed in the case of buttermilk from raw cream, while the reverse seems to be observed in the case of buttermilk from pasteurized cream. The fact that cream pasteurization increased the in vitro micellar solubility of cholesterol in the presence of the resulting buttermilk product thus appeared attenuated by enzymatic hydrolysis using gastrointestinal enzymes. A highly significant $(P=0.0009)$ interaction was observed between heat treatment and proteolysis.

\section{DISCUSSION}

An interesting finding of this study is that significantly lower in vitro cholesterol micellar solubility was found in all butter- milk products obtained from raw cream compared to pasteurized ones. However, the effect of cream pasteurization on the cholesterol-lowering activity is difficult to explain in terms of product composition alone since the samples with and without pasteurization did not have the same protein and lipid compositions.

The relative proportions of the various phospholipids in the buttermilk made from raw cream are in agreement with data reported previously $[22,23]$. The relative proportion of SM, known for its hypocholesterolaemic activity $[6,12,20,21]$, was increased significantly $(P=0.0015)$ in buttermilk from pasteurized cream, confirming earlier data obtained by Morin et al. [17]. However, in spite of this increase, the effect of pasteurization was to increase the in vitro cholesterol micellar solubility of buttermilk solids. This may be due to modifications of the MFGM composition following 
Table IV. Effect of enzymatic hydrolysis of buttermilk solids obtained from raw or pasteurized cream on the in vitro cholesterol micellar solubility.

\begin{tabular}{|c|c|}
\hline Sample & Cholesterol micellar solubility ${ }^{\mathrm{d}}(\%)$ \\
\hline \multicolumn{2}{|l|}{ From raw cream } \\
\hline Non-hydrolysed $^{\mathrm{a}}$ & 70.9 \\
\hline Peptic hydrolysate ${ }^{\mathrm{b}}$ & 73.5 \\
\hline UF permeate $^{\mathrm{c}}$ & 84.5 \\
\hline \multicolumn{2}{|l|}{ From pasteurized cream } \\
\hline Non-hydrolysed $^{\mathrm{a}}$ & 99.0 \\
\hline Peptic hydrolysate $^{b}$ & 88.8 \\
\hline UF permeate ${ }^{c}$ & 82.5 \\
\hline $\operatorname{SEM}(n=3)$ & 2.8 \\
\hline Comparison & Significance $(P$ value $)$ \\
\hline Replicate batches & N.S. ${ }^{\mathrm{e}}$ \\
\hline Heat treatment & $<0.0001$ \\
\hline Fractionation (MF) & N.S. \\
\hline$-($ Buttermilk $) \times($ Permeate \& Retentate $)$ & N.S. \\
\hline$-($ Permeate $) \times($ Retentate $)$ & N.S. \\
\hline$($ Heat treatment $) \times($ MF fractions $)$ & 0.0009 \\
\hline
\end{tabular}

${ }^{\text {a }}$ Freeze-dried low-fat buttermilk in gastric salt solution before the addition of pepsin.

${ }^{\mathrm{b}}$ After $2 \mathrm{~h}$ of treatment with pepsin.

${ }^{c}$ Ultrafiltration (UF) permeate obtained using $30 \mathrm{~kg} \cdot \mathrm{mol}^{-1}$ MWCO membrane after hydrolysis with pepsin $(2 \mathrm{~h})$ and trypsin $(3 \mathrm{~h})$.

${ }^{\mathrm{d}}$ Relative to micellar cholesterol solution without buttermilk product.

${ }^{\mathrm{e}}$ N.S. $=$ non-significant $(P>0.05)$.

heat treatment. It is well known that heatinduced complexes can be formed between whey proteins ( $\beta$-LG and $\alpha$-LA) and MFGM via thiol/disulphide interchange [24, 28, 29]. In fact, it has been reported that a new membrane can result from these new interactions and modify the functional properties of buttermilk [2]. It is possible that adsorption of such proteins interferes with cholesterol fixation by MFGM phospholipids, primarily SM, which is located on the outside of the MFGM along with PC [4]. However, the compositional data reported in the present study did not provide evidence of a direct contribution of phospholipids such as SM to the cholesterol-lowering activity of buttermilk.

Our results also provide evidence that MF fractionation decreases the cholesterol-lowering activity of buttermilk solids. Although
MF retentates were enriched in total lipids and proteins (MFGM and milk proteins) compared to other samples (Figs. 1 and 2), buttermilk from raw cream was significantly more effective than the corresponding MF retentate at reducing the micellar solubility of cholesterol in vitro (Tab. III).

This phenomenon may also result from process-related alterations of the MFGM composition. It has been reported that processing steps such as mechanical agitation, pumping, stirring and homogenization indeed affect the structure and composition of the MFGM [7, 15, 27]. The limited cholesterol-lowering activity observed for fractionated buttermilk (MF permeates and MF retentates) may arise from all the recirculation involved in the MF/DF process, which can induce protein aggregation 
at fragmented MFGM surfaces and decrease the availability of cholesterol-binding sites.

Our results show that the pasteurized fractions recovered their cholesterol-lowering activity after the 5-h sequential digestion with pepsin and trypsin, reducing the effect of pasteurization to insignificance. This result supports the hypothesis that the negative impact of pasteurization on micellar cholesterol solubility reduction capacity of the buttermilk fractions would be due to proteins adsorbed at the surface of MFGM fragments. It can be further hypothesized that following proteolysis by gastric and pancreatic enzymes, the cholesterol-binding sites of MFGM fragments were once again available and the cholesterol-lowering activity of the pasteurized fractions was recovered.

Comparing samples that do not have the same lipid and protein compositions and the absence of in vivo results may be considered as some limitation of the present study. However, this preliminary study aimed at comparing the response of various types of buttermilk fractions as such and at assessing the impact of processing on the in vitro cholesterol-lowering capacity of buttermilk products when exposed to the same amount of freeze-dried samples. Nevertheless, this preliminary study generated relevant data for further in vivo study in our laboratory.

\section{CONCLUSION}

Overall, our results show that buttermilk made from raw cream revealed a lower cholesterol micellar solubilization than buttermilk made from pasteurized cream, based on in vitro measurement. We also demonstrated that processing steps such as pasteurization or MF fractionation may limit the capacity of raw-cream buttermilk to reduce in vitro micellar solubility of cholesterol. Also, hydrolysis by digestive proteases was effective in reversing the negative impact of pasteurization on the cholesterol-lowering activity of buttermilk. Although in vivo studies will be necessary to validate the potential of buttermilk to reduce intestinal absorption of cholesterol, the results of this preliminary study point to new attributes for increasing the commercial value of buttermilk.

Acknowledgements: This work has been supported by a grant from the Natural Sciences and Engineering Research Council of Canada and Dairy Farmers of Canada. The authors wish to thank Johanne Marin for her technical skill in implementing the cholesterol micellar solubility measurement method.

\section{REFERENCES}

[1] Astaire J.C., Ward R., German J.B., Jiménez-Flores R., Concentration of polar MFGM lipids from buttermilk by microfiltration and supercritical fluid extraction, J. Dairy Sci. 86 (2003) 2297-2307.

[2] Corredig M., Dalgleish D.G., Effect of heating of cream on the properties of milk fat globule membrane isolates, J. Agric. Food Chem. 46 (1998) 2533-2540.

[3] Corredig M., Dalgleish D.G., The mechanisms of the heat-induced interaction of whey proteins with casein micelles in milk, Int. Dairy J. 9 (1999) 233-236.

[4] Dewettinck K., Rombaut R., Thienpont N., Le T.T., Messens K., Camp J.V., Nutritional and technological aspects of milk fat globule membrane material, Int. Dairy J. 18 (2008) 436-457.

[5] Donato L., Guyomarc'h F., Formation and properties of the whey protein/ $/$-casein complexes in heated skim milk - A review, Dairy Sci. Technol. 89 (2009) 3-29.

[6] Eckhardt E.R.M., Wang D.Q.-H., Donovan J.M., Carey M.C., Dietary sphingomyelin suppresses intestinal cholesterol absorption by decreasing thermodynamic activity of cholesterol monomers, Gastroenterology 122 (2002) 948-956.

[7] Evers J.M., The milk fat globule membrane compositional and structural changes post secretion by the mammary secretory cell, Int. Dairy J. 14 (2004) 661-674.

[8] Gassi J.-Y., Famelart M.-H., Lopez C., Heat treatment of cream affects the physicochemical properties of sweet buttermilk, Dairy Sci. Technol. 88 (2008) 369-385. 
[9] IDF, Milk and Milk Products - Determination of Nitrogen Content-Routine Method Using Combustion According to the Dumas Principle, Standard 185, Int. Dairy Fed., Brussels, Belgium, 2002.

[10] IDF, Skim Milk, Whey and Buttermilk Determination of Fat Content-Gravimetric Method (Reference Method), Standard 22, Int. Dairy Fed., Brussels, Belgium, 2008.

[11] Ikeda I., Tanaka K., Vahouny G.V., Gallo L.L., Inhibition of cholesterol absorption in rats by plant sterols, J. Lipid Res. 29 (1988) 1573-1582.

[12] Kobayashi T., Shimizugawa T., Osakabe T., Watanabe S., Okuyama H., A long-term feeding of sphingolipids affected the levels of plasma cholesterol and hepatic triacylglycerol but not tissue phospholipids and sphingolipids, Nutr. Res. 17 (1997) 111-114.

[13] Laemmli U.K., Cleavage of structural proteins during the assembly of the head of bacteriophage T4, Nature 227 (1970) 680 685.

[14] Mather I.H., A review and proposed nomenclature for major proteins of milk-fat globule membrane, J. Dairy Sci. 83 (2000) 203-247.

[15] McPherson A.V., Kitchen B.J., Reviews of the progress of dairy science: the bovine milk fat globule membrane - its formation, composition, structure and behaviour in milk and dairy products, J. Dairy Res. 50 (1983) 107-133.

[16] Minekus M., Marteau P., Havenaar R., Huis In't Veld J.H.J., A multicompartmental dynamic computer-controlled model simulating the stomach and small intestine, Altern. Lab. Anim. 23 (1995) 197-209.

[17] Morin P., Jiménez-Flores R., Pouliot Y., Effect of temperature and pore size on fractionation of fresh and reconstituted buttermilk by microfiltration, J. Dairy Sci. 87 (2004) 267-273.

[18] Morin P., Jiménez-Flores R., Pouliot Y., Effect of processing on the composition and microstructure of buttermilk and its milk fat globule membranes, Int. Dairy J. 17 (2007) 1179-1187.

[19] Nagaoka S., Futamura Y., Miwa K., Awano T., Yamauchi K., Kanamaru Y., Tadashi K., Kuwata T., Identification of novel hypocholesterolemic peptides derived from bovine milk beta-lactoglobulin, Biochem. Biophys. Res. Commun. 281 (2001) 11-17.

[20] Noh S.K., Koo S.I., Egg sphingomyelin lowers the lymphatic absorption of cholesterol and alpha-tocopherol in rats, J. Nutr. 133 (2003) 3571-3576.

[21] Noh S.K., Koo S.I., Milk sphingomyelin is more effective than egg sphingomyelin in inhibiting intestinal absorption of cholesterol and fat in rats, J. Nutr. 134 (2004) 26112616.

[22] Rombaut R., Camp J.V., Dewettinck K., Analysis of phospho- and sphingolipids in dairy products by a new HPLC method, J. Dairy Sci. 88 (2005) 482-488.

[23] Rombaut R., Dewettinck K., Properties, analysis and purification of milk polar lipids, Int. Dairy J. 16 (2006) 1362-1373.

[24] Singh H., The milk fat globule membrane a biophysical system for food applications, Curr. Opin. Colloid Interface Sci. 11 (2006) 154-163.

[25] Sodini I., Morin P., Olabi A., Jiménez-Flores R., Compositional and functional properties of buttermilk: a comparison between sweet, sour, and whey buttermilk, J. Dairy Sci. 89 (2006) 525-536.

[26] Spitsberg V.L., Invited review: bovine milk fat globule membrane as a potential nutraceutical, J. Dairy Sci. 88 (2005) 2289-2294.

[27] Ward R.E., German J.B., Corredig M., Composition, applications, fractionation, technological and nutritional significance of milk fat globule membrane material, in: Fox P.F., Mcsweeney P.L.H. (Eds.), Advanced Dairy Chemistry, Volume 2: Lipids, Springer, New York, USA, 2006.

[28] Ye A., Singh H., Taylor M.W., Anema S., Characterization of protein components of natural and heat-treated milk fat globule membrane, Int. Dairy J. 12 (2002) 393-402

[29] Ye A., Singh H., Taylor M.W., Anema S., Interactions of whey proteins with milk fat globule membrane proteins during heat treatment of whole milk, Lait 84 (2004) 269-283.

[30] Zlatkis A., Zak B., Study of a new cholesterol reagent, Anal. Biochem. 29 (1969) 143-148. 